\title{
Pengembangan Media Pembelajaran Bahasa Inggris yang Praktis dan Efektif Menggunakan Moodle
}

\author{
Risdal Yosli*1, Hasan Maksum² \\ ${ }^{1,2}$ Program Studi Magister Pendidikan Teknologi dan Kejuruan, Universitas Negeri Padang \\ email: rajoperak@gmail.com ${ }^{1}$,maksum.hasan@gmail.com ${ }^{2}$
}

(Received: 24 Oktober 2021 / Accepted: 25 November 2021 / Published Online: 20 Desember 2021)

\begin{abstract}
Abstrak
Metode penyampaian pembelajaran secara lisan serta pemberian catatan berupa foto copy atau pun catatan, kurang efektif dalam penghematan waktu dan kurang maksimal diperoleh oleh siswa. Tujuan penelitian ini adalah untuk menghasilkan media pembelajaran yang praktis dan efektif digunakan oleh guru dan siswa di Sekolah Menengah Kejuruan. Media pembelajaran berbasis web menggunakan moodle 3.11.3+ yang diaplikasikan pada domain dan hosting. Jenis penelitian ini adalah R \& D (Research \& Development), dan model pengembangan produk adalah 4D; Define, Design, Develop dan Disseminate. Instrumen yang digunakan angket media, materi, kepraktisan dan butir-butir soal Bahasa Inggris. Subjek penelitian adalah guru dan siswa SMK Pratama Padang. Teknik analisa data yaitu uji validitas produk, teknik analisis kepraktisan dan teknis analisis efektifitas produk. Tingkat kepraktisan produk yaitu 85 (responden guru) pada kategori praktis dan 81,99 (responden siswa) pada kategori sangat praktis. Tingkat efektifitas produk berdasarkan gain score mencapai 0,45 yaitu pada kategori sedang.
\end{abstract}

Kata kunci: 4D, Media Pembelajaran, Moodle, Web

\begin{abstract}
The method of delivering learning by orally as well as giving a note in the form of copy or note, is less successful in time and is not maximally obtained by a student. The purpose of this research is to produce practical and effective learning media used by teacher and student at vocational high school. Web-based learning media using model 3.11.3+, which is applied to the domain and hosting. The type of this research is $R \& D$ (research \& development), and the product development models are $4 D$; define, design, develop and disseminate. The instruments used are questionnaire, material, practically and English questions. The subjects of research are teacher and student of SMK Pratama Padang. Data analysis techniques are product validity testing, practical analysis technique and product effectiveness analysis technique. The levels of practicality of the product are 85 (teacher's respondent) in the practical category and 81.99 (student's respondent) in the very practical category. The level of product effectiveness based on the gain score reached 0.45, in the medium category.
\end{abstract}

Keywords: 4D, Learning Media, Moodle, Web

\section{PENDAHULUAN}

Secara umum mata pelajaran ini disajikan berupa materi dan praktikum berbahasa dilakukan berupa dialog lisan dan tulisan. Kami telah melakukan observasi dengan mewawancarai langsung guru mata pelajaran Bahasa Inggris SMK Pratama Padang. Temuantemuan dalam observasi seperti perbedaan daya tangkap belajar siswa, selama masa di kelas $\mathrm{X}$ adalah untuk mengukur kembali kemampuan siswa, setelah di kelas XI untuk menyamakan dan meningkatkan kemampuan siswa, dan di kelas XII menguasai materi pembelajaran sesuai tingkat. Perangkat pendukung pembelajaran yang ada di sekolah berupa infocus, guru menyampaikan pembelajaran berupa power point. Dalam proses pembelajaran guru menyampaikan materi satu arah yaitu berbentuk tulisan, gambar serta visual. Tanggapan 
siswa terhadap berbahasa inggris pun berbeda, ada menganggap sebagai gaya hidup, ada yang menggunakan untuk bernyanyi. Tanggapan siswa seperti ini merupakan ekspresi siswa atau gaya belajar mereka. Belajar merupakan dasar dari rancangan kurikulum yang memiliki keterkaitan antara tujuan atau standar, penilaian, kegiatan dan materi (Sopiatin, 2010, p. 45). Gaya belajar merupakan cara siswa dalam mengolah informasi yang yang telah didapatkan sesuai dengan karakteristik siswa masing-masing (Dharmayanti et al., 2021), Setelah proses pembelajaran, materi yang disampaikan oleh guru secara umum bagi siswa tidak lagi menjadi kebutuhan untuk diulang kembali saat di rumah. Serta merta interaksi berbahasa inggris di luar jam pembelajaran tidak terlaksana sama sekali.

Fungsi intenet sebagai media dalam kegiatan pembelajaran, yaitu sebagai (1) komplemen (pelengkap), (2) suplemen (tambahan), atau (3) substitusi (pengganti) terhadap pembelajaran di lembaga pendidikan (Munir, 2009, p. 161). Pembelajaran dalam jaringan atau secara online disebut juga e-learning. E-learning merupakan sistem pendidikan yang dapat diakses dengan menggunakan internet yang dapat menyimpan atau memunculkan kembali, mendistribusikan, berbagi ilmu dan informasi yang berguna untuk memaksimalkan bentuk pembelajaran jarak jauh, Kapezovich \& Toktarbekovna (Kawuri et al., 2019). Elearning adalah alternatif yang menjanjikan untuk pembelajaran di kelas tradisional, yang sangat bermanfaat untuk pembelajaran dan pelatihan jarak jauh dan seumur hidup (Goyal, 2012).

Media berfungsi secara efektif dalam konteks pembelajaran yang berlangsung tanpa menuntut kehadiran guru pembelajaran (Lestari \& Pratama, 2020; Maisiswati et al., 2018; Siddik \& Kholisho, 2019). E-Learning merupakan pembelajaran langsung dimana dalam penerapannya mengedepankan pembelajaran mandiri yaitu pembelajaran jarak jauh berbasis Web yang bisa diakses melalui jaringan internet (Maulana, 2020). Munir (2009: 17), pembelajaran jarak jauh akan efektif jika melibatkan interaksi antara pembelajar dengan pengajar, pembelajar dengan pembelajar, pembelajar dengan media (termasuk fasilitas) pembelajaran. Salah satu software open source dari e-learning yang dapat diterapkan dalam proses pembelajaran adalah Moodle, pemanfaatan software open source Moodle ini tidak diperlukan biaya atau gratis (Muazizah et al., 2016). E-learning merupakan transformasi belajar biasa ke bentuk digital yang dijembatani oleh teknologi internet (Gora, 2005).

Prinsip yang terkandung di dalam e-learning diantaranya: (1) e-learning sebagai alat bantu proses pembelajaran sehingga dapat menyelesaikan masalah, menghasilkan kreativitas, membuat proses pembelajaran lebih mudah, terarah dan bermakna, (2) e-learning sebagai sebuah alternatif dalam sistem pendidikan yang memiliki prinsip high-tech-high-touch yaitu prosesnya lebih banyak bergantung kepada teknologi canggih dan yang lebih penting adalah aspek "high touch" yaitu pengajar atau pembelajar. (3) sesuaikan e-learning dengan kesiapan pengajar dan pembelajar, fasilitas dan kultur sistem belajar (Munir, 2009). Melalui e-learning proses mentransfer informasi dari guru ke siswa lebih fleksibel sehingga pembelajaran dapat dilakukan dimana saja dan kapan saja (Azmi et al., 2020)

MOODLE (Modular Object-Oriented Dynamic Learning Environment) adalah LMS (Learning Management System) digunakan untuk memuat materi pembelajaran dan ditampilkan ke laman web. Moodle merupakan perangkat lunak e-learning open-source yang kemudian lebih dikenal setelah dikembangkan oleh Martin Dougiamas yang mengikuti pendekatan konstruksionis sosial (Quesada et al., 2013). Aplikasi Moodle mudah dalam penginstalan, tersedia fitur-fitur seperti admin, user, pengisian materi atau modul pelajaran hingga pemakaian. Aplikasi ini dapat diterapkan secara offline pada ruang lingkup labor di sekolah maupun secara online melalui website. Dengan aplikasi ini tenaga pengajar dapat menyimpan serta mengirim materi pelajaran dan tugas. Sehingga manfaat yang didapat bagi siswa, pembelajaran tanpa harus di kelas sehingga memudahkan siswa dalam mengulang 
pelajaran. Media pembelajaran dapat membuat suasana belajar siswa menjadi menyenangkan karena siswa terbantu dalam belajar (Indra et al., 2021).

Bagi guru dan sekolah, media pembelajaran ini bermanfaat sebagai alternatif penerapan pembelajaran, sehingga penyampaian materi kepada siswa dapat diselesaikan lebih cepat atau sesuai waktu yang direncanakan. Hasil analisis kebutuhan siswa di SMKN 1 Sintuk Toboh Gadang, 78\% siswa kesulitan memahami materi dengan media pembelajaran dalam bentuk powerpoint dan buku ajar (Azmi, 2020). Kebutuhan peserta didik untuk mendapatkan aspek pembelajaran dengan pembelajaran daring cukup terpenuhi, tujuan dari pembelajaran dari cukup terpenuhi dan misi dari pembelajaran daring cukup terpenuhi (Hanif et al., 2021). Secara keseluruhan pencapaian kreativitas matematis siswa kemampuan berpikir yang menggunakan pembelajaran PjBL dengan LMS Moodle lebih baik daripada siswa yang menggunakan pembelajaran konvensional (Sudianto et al., 2019). MEP (moodle e-learning platform) adalah alat e-learning yang kuat dan memberikan kesempatan bagi guru untuk memvariasikan pengajarannya dengan cara yang melibatkan siswa dan meningkatkan minat mereka dalam partisipasi mandiri dalam kegiatan kursus (Amandu et al., 2013).

Beberapa peneliti telah mengembangkan media pembelajaran menggunakan moodle untuk mata pelajaran berbeda. Seperti pada penelitian yang dilakukan oleh (Kawuri et al., 2019) yang mengimplementasikan e-learning berbasis moodle pada mata pelajaran fisika. Penelitian (Muazizah et al., 2016) menerapkan e-learning berbasis moodle dalam peningkatan hasil belajar siswa pada materi hidrokarbon SMA kelas XI. Marsa \& Yunita (2019) menggunakan moodle sebagai platform media pembelajaran matematika pada website. Pengembangan media pembelajaran berbasis web menggunakan moodle yang layak, praktis dan efektif digunakan juga berhasil dikembangkan oleh Azmi (2020) pada mata pelajaran Administrasi Infrastruktur Jaringan di SMKN 1 Sintuk Toboh Gadang. Berdasarkan penelitian-penelitian pada media pembelajaran menggunakan moodle oleh peneliti-peneliti tersebut, maka software moodle layak digunakan sebagai platform dan website sebagai basis media pembelajaran pada penelitian ini.

Media pembelajaran berbasis web menggunakan moodle ini dikembangkan untuk memvariasikan media dan model pembelajaran, dari penggunaan media seperti powerpoint, papan tulis, foto copy dan lisan ditambah dengan ketersediaan materi dan soal-soal latihan mata pelajaran dalam satu perangkat serta diakses kapan pun secara online. Materi dan soalsoal latihan dapat diakses pada media yang sudah akrab digunakan oleh guru dan siswa tentunya akan menambah pembendaharaan objek perhatian pada perangkat teknologi seperti android. Kebiasaan setiap saat individu menggunakan teknologi android terutama siswa, akan termotivasi mengakses pembelajaran secara online dibanding membaca catatan atau buku pelajaran. Guru di dalam maupun di luar kelas lebih mudah menyampaikan materi pelajaran kepada siswa, karena beberapa kegiatan sudah diefektifkan seperti tidak perlu lagi memberi catatan, menerangkan secara lisan, karena sudah tergantikan dengan adanya file video, serta soal-soal latihan di dalam media.

Berdasarkan beberapa permasalahan dan penelitian sebelumnya, pada penelitian ini bertujuan untuk menghasilkan media pembelajaran pada mata pelajaran Bahasa Inggris SMK yang valid, praktis dan efektif digunakan dengan bantuan aplikasi moodle.

\section{METODE}

Jenis penelitian yang diterapkan adalah model pengembangan penelitian R\&D (Research and Development) yang bertujuan menghasilkan produk aplikasi tertentu serta melakukan pengujian terhadap keefektifan produk tersebut (Sugiyono, 2006, p. 297). Model pengembangan penelitian $\mathrm{R} \& \mathrm{D}$ adalah mencari temuan, merumuskan, mengembangkan atau menghasilkan produk, menguji keefektifan produk, prosedur tertentu yang lebih unggul, produk yang praktis dan efektif. Pengembangan penelitian R\&D diterapkan dengan 4D. 
Tahapan 4D; (1) define (pendefinisian), (2) design (perancangan), (3) develop (pengembangan), (4) disseminate (penyebaran) (Trianto, 2012, p. 189)

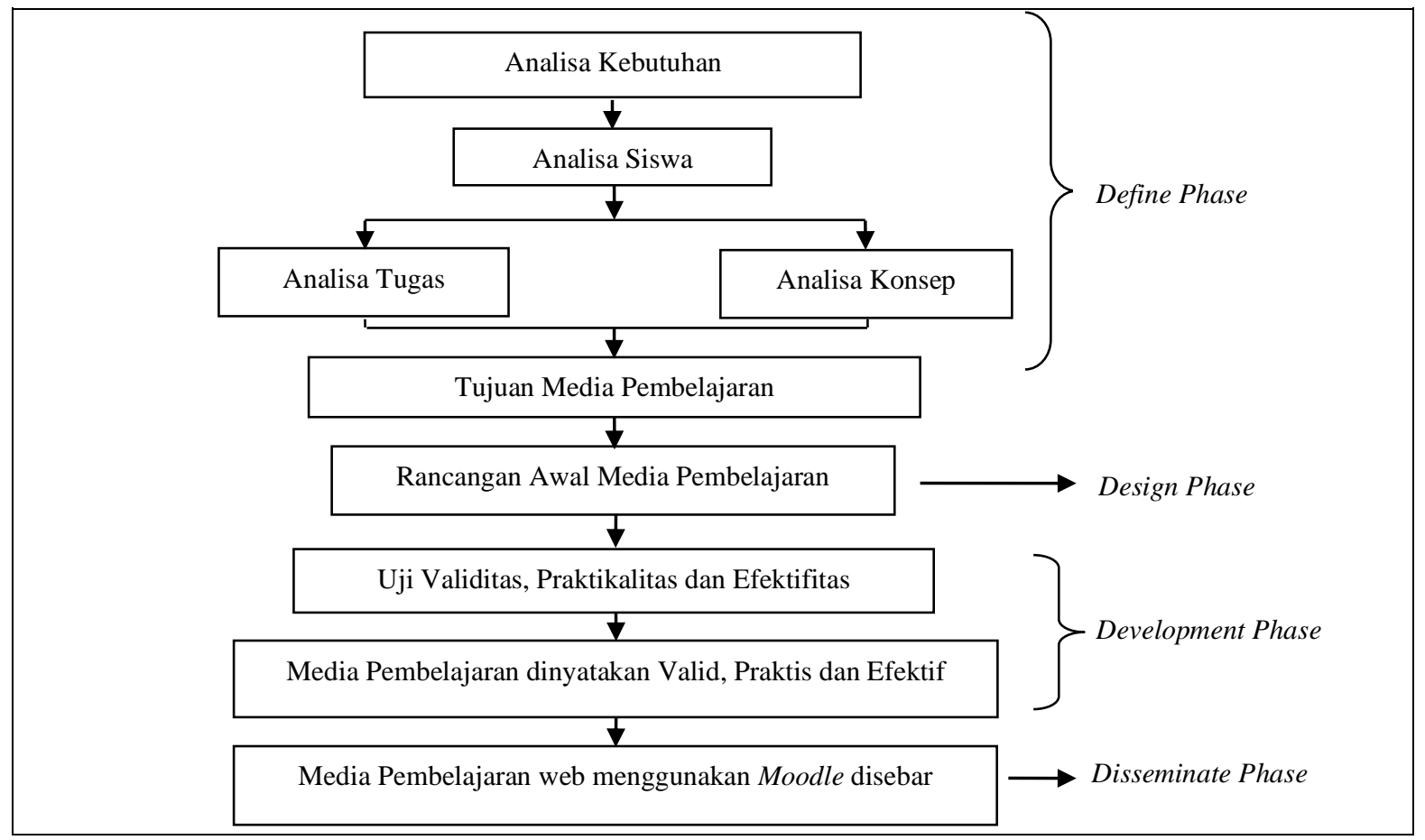

Gambar. 1 Desain Penelitian

Tahapan penelitian dilakukan seperti yang ditampilkan pada gambar 1. Pada tahap define (pendefinisian) dilakukan observasi dan analisa-analisa untuk merumuskan permasalahan yang diangkat sehingga ditentukan tujuan media pembelajaran. Observasi selama beberapa bulan yaitu antara Januari sampai Juni 2021 di SMK Pratama Padang. Pada tahap kedua yaitu design (mendesain) sekaligus mengembangkan media pembelajaran yang sesuai digunakan pada mata pelajaran Bahasa Inggris SMK. Sarana atau media pembelajaran secara online yang dirancang dalam penelitian ini adalah moodle yang dipasang pada website. Website yang terdiri dari domain dan hosting disewa sebelum penelitian dimulai. Selanjutnya pada tahap pengembangan (develop), aplikasi moodle dipasang pada hosting. Pada moodle, materi dan latihan-latihan diisikan sesuai dengan buku pegangan guru yang biasa disampaikan kepada peserta didik. Riset dalam tahap pengembangan (develop) dilakukan untuk mengetahui tingkat kevalidan, kepraktisan dan keefektivan media pembelajaran berbasis web menggunakan moodle. Subjek penelitian adalah siswa dan guru SMK Pratama Padang.

Data yang dikumpulkan adalah data primer, yaitu data yang diperoleh langsung dari responden. Data-data yang dikumpulkan diantaranya data uji validitas media dan materi dari para ahli yaitu dosen dan guru bidang studi. Data uji praktikalitas tentang media pembelajaran yang dikembangkan diambil dari jawaban responden guru dan siswa. Keefektifan produk diuji melalui pretest dan posttest pada siswa, hingga diperoleh Gain Score.

\section{HASIL DAN PEMBAHASAN \\ Hasil}

Pada tahap define, dilakukan kegiatan observasi yaitu mewawancarai guru mata pelajaran bahasa inggris SMK Pratama Padang. Dalam wawancara dibutuhkan media yang menarik dan memuat materi serta latihan-latihan terintegrasi dalam satu wadah media. 
Selanjutnya hasil analisa siswa, ketersediaan materi dan soal-soal latihan yang dapat diakses melalui perangkat komunikasi yaitu android sejalan dengan kemampuan siswa dalam menggunakannya. Hasil analisa tugas, acuan pengembangan materi dalam media pembelajaran ini adalah Kompetensi Dasar yang diterapkan berdasarkan buku pegangan pokok guru dalam menyampaikan materi. Analisa konsep, mengembangkan pembelajaran menggunakan moodle dalam website sama halnya dengan adanya suatu sekolah yang terdiri dari kelas. Perumusan tujuan media pembelajaran, penggunaan media pembelajaran web dengan moodle ini dirumuskan agar guru dan siswa dapat melaksanakan tujuan pembelajaran.

Tahap design, rancangan awal media pembelajaran dimulai dari penyediaan web yang terdiri dari domain dan hosting, pada hosting diinstalkan aplikasi moodle. Setelah aplikasi moodle tersedia, course atau kelas dibuat, lalu materi-materi dan soal-soal latihan diisikan. Pada tahap development, media dan materi diuji kevalidannya oleh ahli validasi. Selanjutnya pada guru dan siswa diuji tingkat kepraktisan dan keefektifan media pembelajaran ini.

Tabel 1. Validasi Materi

\begin{tabular}{ccc}
\hline \multirow{2}{*}{ Aspek Validasi } & \multicolumn{2}{c}{ Aiken's V } \\
\cline { 2 - 3 } & Validator 1 & Validator 2 \\
\hline Kualitas Materi & 1 & 0,89 \\
Kualitas Pembelajaran & 0,70 & 0,90 \\
Kualitas Interaksi & 0,94 & 0,81 \\
Kualitas Tampilan & 1 & 0,85 \\
Rata-rata Validator & 0,91 & 0,86 \\
Rata-Rata & \multicolumn{2}{c}{0,88} \\
\hline
\end{tabular}

Pada tabel 1, validator 1 (dosen) dan validator 2 (guru) adalah ahli materi yang menguji kualitas materi, kualitas pembelajaran, kualitas interaksi dan kualitas tampilan. Rata-rata semua aspek yang diuji diperoleh 0,88 yaitu pada kategori sangat valid. Sementara itu, Pada tabel 2 adalah hasil validasi media oleh ahli media. validator 1 (dosen) dan validator 2 (guru) adalah ahli media yang menguji aspek syarat didaktik, syarat konstruksi dan aspek teknis. Rata-rata semua aspek yang diuji diperoleh 0,73 yaitu pada kategori valid. Uji kepraktisan produk pada responden guru yang disajikan pada tabel 3, aspek yang dinilai yaitu kemudahan penggunaan media, efektifitas waktu dan penggunaan media, diperoleh rata-rata $85 \%$ yaitu pada kategori sangat praktis.

Tabel 2. Validasi Media

\begin{tabular}{ccc}
\hline \multirow{2}{*}{ Aspek Validasi } & \multicolumn{2}{c}{ Aiken's V } \\
\cline { 2 - 3 } & Validator 1 & Validator 2 \\
\hline Syarat Didaktik & 0,69 & 0,75 \\
Syarat Konstruksi & 0,63 & 0,79 \\
Aspek Teknis & 0,67 & 0,83 \\
Rata-rata Validator & 0,66 & 0,79 \\
Rata-Rata & \multicolumn{2}{c}{0,73} \\
\hline
\end{tabular}

Uji kepraktisan produk pada responden siswa yang disajikan pada tabel 4, aspek yang dinilai yaitu kemudahan penggunaan media, efektifitas waktu dan manfaat atau penggunaan media, diperoleh rata-rata 81,99\% yaitu pada kategori sangat praktis. Berdasarkan tabel 3 dan 4, uji kepraktisan yang dilakukan pada responden guru dan siswa diperoleh hasil bahwa media pembelajaran ini berada pada kategori sangat praktis. 
Tabel 3. Hasil Uji Praktikalitas Responden Guru

\begin{tabular}{cccc}
\hline \multirow{2}{*}{ Aspek Penilaian } & \multicolumn{3}{c}{ Rata-rata Nilai } \\
\cline { 2 - 4 } & Guru 1 & Guru 2 & Guru 3 \\
\hline Kemudahan Penggunaan Media & $90 \%$ & $90 \%$ & $83 \%$ \\
Efektifitas Waktu & $70 \%$ & $70 \%$ & $80 \%$ \\
Penggunaan Media & $95 \%$ & $95 \%$ & $90 \%$ \\
Rata-rata Penilaian Guru & $85 \%$ & $85 \%$ & $84 \%$ \\
Rata-rata & \multicolumn{3}{c}{$85 \%$} \\
Kategori & \multicolumn{3}{c}{ Sangat Praktis } \\
\hline
\end{tabular}

Tabel 4. Hasil Uji Praktikalitas Responden Siswa

\begin{tabular}{cc}
\hline Aspek & Rata-rata \\
\hline Kemudahan Penggunaan Media & $83,40 \%$ \\
Efektivitas Waktu & $79,20 \%$ \\
Manfaat atau Penggunaan Media & $83,38 \%$ \\
Rata-rata & $81,99 \%$ \\
Kategori & Sangat Praktis \\
\hline
\end{tabular}

Uji keefektifan dilakukan dengan cara pretest dan posttest, selanjutnya dihitung $N$ gain atau gain score yaitu untuk mengetahui peningkatan nilai hasil belajar setelah menggunakan produk yang dikembangkan. Pada tabel 5, hasil pretest dan posttest diperlakukan pada 16 orang siswa. Pretest dilakukan sebelum penggunaan produk atau media pembelajaran. Setelah pretest, siswa diperlakukan dalam belajar memanfaatkan media pembelajaran berbasis web menggunakan moodle. Sementara posttest dilakukan setelah siswa diberikan perlakuan yaitu kegiatan pembelajaran menggunakan media pembelajaran berbasis web dengan moodle. Berdasarkan tabel 5, terdapat perbedaan hasil belajar atau ketuntasan klasikal yang signifikan antara pretest dan posttest. Persentase tuntas saat pretest hanya $18,75 \%$, sementara tuntas saat posttest adalah $87,5 \%$. Peningkatan atau rata-rata $N$ gain atau gain score adalah 0,45 atau kategori sedang.

Tabel 5. Hasil Pretest dan Posttest

\begin{tabular}{cccccc}
\hline \multirow{2}{*}{ Kegiatan } & Jumlah & \multicolumn{2}{c}{ Hasil Belajar } & \multicolumn{2}{c}{ Persentase } \\
\cline { 2 - 6 } & Siswa & Tuntas & Tidak Tuntas & Tuntas & Tidak Tuntas \\
\hline Pretest & 16 & 3 & 13 & $18,75 \%$ & $81,25 \%$ \\
\hline Posttest & 16 & 14 & 2 & $87,5 \%$ & $12,5 \%$ \\
\hline
\end{tabular}

Tabel 6. Gain Score

\begin{tabular}{cccc}
\hline $\mathbf{N}$ & Gain Score Min & Gain Score Max & Gain Score \\
\hline $\mathbf{1 6}$ & 0,17 & 0,89 & 0,45 \\
\hline \multicolumn{3}{c}{ Kategori } \\
\hline
\end{tabular}

Uji efektifitas produk terhadap hasil belajar yang nampak pada tabel 6, memperoleh ketuntasan secara klasikal mencapai $87,5 \%$ dan gain score 0,45 dengan kategori sedang, maka dapat disimpulkan bahwa media pembelajaran berbasis web dinyatakan efektif.

Media pembelajaran menggunakan moodle ini dapat diakses melalui browsing di laptop dan android. Berikut tampilan-tampilan media pembelajaran di android, link https://elearningpratama.com. Gambar 2 merupakan tampilan depan media pembelajaran 
menggunakan moodle saat dibuka melalui perangkat android. Selanjutnya, gambar 3 saat user sudah login ke aplikasi moodle. Mata pelajaran Bahasa Inggris yang telah dibuat tampil pada menu courses.

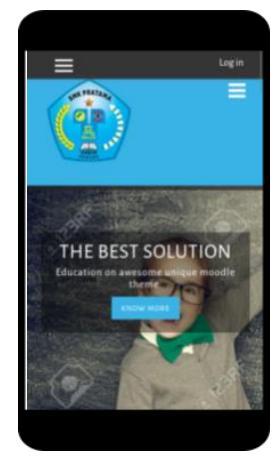

Gambar 2. Tampilan Moodle di Android

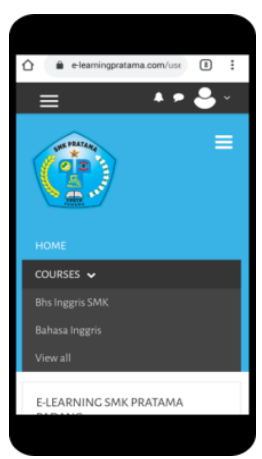

Gambar 3. Course

\section{Pembahasan}

Temuan dari observasi memotivasi peneliti untuk mengembangkan media pembelajaran serta meneliti apakah media ini praktis dan efektif digunakan. Motivasi peneliti melakukan observasi hingga pengembangan media pembelajaran ini didasari terus berlangsungnya pembelajaran secara online. Penggunaan perangkat komunikasi yaitu android serta mediamedia sosial sebagai saluran pembelajaran. Berdasarkan wawancara dengan guru mata pelajaran Bahasa Inggris SMK Pratama Padang, dibutuhkan media pembelajaran yang memuat materi dan latihan, serta media yang dapat meningkatkan motivasi belajar siswa. Selanjutnya dilakukan analisa untuk menyesuaikan antara kebutuhan serta ketersediaan teknologi yang dapat diterapkan dalam menghasilkan media pembelajaran yang diinginkan.

Media pembelajaran berbasis web menggunakan moodle ini layak digunakan pada mata pelajaran teori seperti Bahasa Inggris di SMK. Tahapan-tahapan uji dilakukan diantaranya pengembangan produk, menguji validitas media dan materi, menyebar kuisioner untuk mengukur tingkat kepraktisan, serta melaksanakan pretest dan posttest untuk menguji keefektifan produk. Hasil uji kepraktisan pada guru dan siswa pada kategori sangat praktis dan praktis, hal ini karena dipengaruhi aspek penggunaan, manfaat dan efektifitas waktu. Selanjutnya berdasarkan hasil Gain score atau kenaikan nilai dari pretest ke posttest, artinya dapat meningkatkan hasil belajar siswa, maka dinyatakan media pembelajaran ini efektif digunakan. Berdasarkan observasi awal ditemukan permasalahan dalam proses belajar Bahasa Inggris di SMK, selanjutnya uji validitas media dan materi, uji kepraktisan kepada guru dan siswa, dilengkapi dengan uji keefektifan melalui pretest dan posttest, menghasilkan data-data penelitian berupa angka-angka pada tabel-tabel, maka kami menyatakan bahwa 
media pembelajaran berbasis web menggunakan moodle ini layak, valid, praktis dan efektif digunakan.

Hasil penelitian ini relevan dengan hasil penelitian sebelumnya yang dilakukan oleh (Azmi, 2020), dan hasil penelitian (Nikmah, 2015), dimana hasil uji validasi materi adalah valid. Hasil penelitian (Azmi, 2020) dan (Nikmah, 2015) media pembelajaran yang mereka kembangkan dinyatakan valid dan layak digunakan. Terdapat perbedaan dengan penelitian ini yaitu hasil uji validasi materi sangat valid. Sementara pada penelitian relevan sebelumnya yaitu Azmi, 2020 dan Nikmah, 2015 hasil uji validasi materi valid.

Simulasi penggunaan media pembelajaran ini kepada guru dan siswa tidak mengalami kendala, karena tersedia link, username dan password untuk setiap user serta lancarnya akses internet. Setelah dirasa cukup penguasaan penggunaan media oleh siswa, peneliti melaksanakan uji praktikalitas dan uji efektifitas produk. Dalam menjawab kuisioner uji praktikalitas, ditemukan kekurangpraktisan memahami fitur-fitur oleh siswa karena bahasa yang digunakan oleh media adalah Bahasa Inggris. Hal ini terjadi karena media termasuk teknologi yang baru ditemui oleh siswa, dan keadaan ini tidak butuh waktu lama dapat diatasi oleh siswa. Artinya, ketidakpahaman hingga menganggap kurang praktis pada bagian tertentu di media dapat diatasi bila dibiasakan menggunakan media tersebut.

Tingkat keefektifan media pembelajaran dilakukan uji kepada siswa yaitu melalui tahapan-tahapan pretest dan posttest. Setelah pretest diketahui hasil belajar siswa, diantaranya kurangnya penguasaan kata hingga pemahaman maksud kalimat. Pada media pembelajaran yang peneliti kembangkan disediakan materi berupa teks dan video, siswa menjadi tertarik untuk memperhatikan materi tersebut, hal ini dibuktikan dengan adanya beberapa siswa memutar video materi. Hasil pengamatan peneliti, saat sebelum media pembelajaran disediakan, siswa memperhatikan guru menyampaikan materi, namun cenderung menimbulkan kejenuhan dalam belajar. Berbeda saat siswa menggunakan media pembelajaran yang peneliti sediakan, rata-rata siswa antusias mengikuti pembelajaran yang disertai mendengarkan materi dalam video. Selanjutnya dilakukan posttest, yaitu uji kompetensi setelah diberi perlakuan menggunakan media pembelajaran. Perbandingan antara pretest dan posttest yaitu kenaikan skor atau gain score pada kategori sedang. Kategori sedang didapat karena kemampuan siswa dalam menguasai materi pembelajaran meningkat setelah pretest. Kategori gain score sedang dapat dikatakan sebagai tingkat keefektifan sedang. Dengan demikian, media pembelajaran ini efektif digunakan oleh guru dan siswa SMK dalam belajar Bahasa Inggris. Hasil gain score atau efektif pada kategori sedang juga diperoleh dari penelitian (Azmi, 2020). Perbedaan penelitian ini dengan penelitian (Azmi, 2020) adalah pada rata-rata akhir gain score. Gain score lebih tinggi karena jarak antara gain score minimum dengan gain score maksimum lebih tinggi. Sementara pada penelitian ini jarak antara gain score minimum dengan gain score maksimum tidak lebih tinggi dari penelitian.

\section{SIMPULAN}

Media pembelajaran Bahasa Inggris pada penelitian ini layak digunakan karena tingkat validasi media yang valid dan materi sangat valid. Selanjutnya kelayakan dibuktikan dengan tingkat kepraktisan yang sangat praktis dan efektifitas pada kategori sedang. Dari nilai-nilai yang didapat pada penelitian nampak kelebihan dan kekurangan media serta materi pembelajaran yang digunakan. Kelebihan media diantaranya dapat diakses menggunakan perangkat yang biasa digunakan oleh guru dan siswa, yaitu android. Artinya guru dan siswa sebagai user, dengan sedikit panduan dapat segera memahami penggunaan media pada perangkatnya. Hal inilah yang membuat tingkat kepraktisan pada kategori sangat praktis meskipun pada uji validasi oleh ahli hanya pada kategori valid. Sementara tingkat validitas materi pada kategori sangat valid karena materi bersumber dari buku pegangan guru, tetapi 
tingkat keefektifan pada kategori sedang. Hal ini terjadi karena tingkat pemahaman siswa terhadap materi pembelajaran pada kategori sedang. Kesimpulan dari hasil penelitian dan pengembangan ini adalah, media pembelajaran Bahasa Inggris menggunakan moodle di SMK layak, valid, praktis dan efektif digunakan.

\section{REFERENSI}

Amandu, G. M., Muliira, J. K., \& Fronda, D. C. (2013). Using Moodle E-learning Platform to Foster Student Self-directed Learning: Experiences with Utilization of the Software in Undergraduate Nursing Courses in a Middle Eastern University. Procedia - Social and Behavioral Sciences, 93, 677-683. https://doi.org/10.1016/j.sbspro.2013.09.260

Azmi, R. A. (2020). Pengembangan Media Pembelajaran Berbasis Web Menggunakan Moodle Pada Mata Pelajaran Administrasi Infrastruktur Jaringan di SMKN 1 Sintuk Toboh Gadang. Tesis. Universitas Negeri Padang.

Azmi, R. A., Rukun, K., \& Maksum, H. (2020). Analisis Kebutuhan Pengembangan Media Pembelajaran Berbasis Web Mata Pelajaran Administrasi Infrastruktur Jaringan. Jurnal Imiah Pendidikan Dan Pembelajaran, 4(2), 303-314.

Dharmayanti, W., Dharmayanti, W., \& Nurcahyo, R. W. (2021). Analisis dan Perancangan ELearning Adaptif di Sekolah Menengah Kejuruan. Edumatic: Jurnal Pendidikan Informatika, 5(1), 1-10. https://doi.org/10.29408/edumatic.v5i1.2544

Gora, W. (2005). Belajar Sendiri Membuat CD Multimedia Interaktif untuk Bahan Ajar ELearning. Jakarta: PT. Elex Media Komputindo.

Goyal, S. (2012). E-Learning: Future of Education. Journal of Education and Learning (EduLearn), 6(2), 239-242. https://doi.org/10.11591/edulearn.v6i4.168

Hanif, H., Maksum, H., \& Irfan, D. (2021). Evaluasi Pembelajaran Daring Dismk Negeri 1 Sumatera Barat. Jurnal Education and Development, 9(2), 156-161.

Indra, D., Maksum, H., \& Abdullah, R. (2021). Meningkatkan Hasil Belajar Komputer dan Jaringan Dasar Melalui Media Pembelajaran Interaktif. Jurnal Edutech Undiksha, 8(1), $14-22$.

Kawuri, M. Y. R. T., Jufriansyah, A., Setiamukti, D. D., \& Sulisworo, D. (2019). Implementation E-Learning Based Moodle on Physics Learning in Senior High School. Indonesian Journal of Science and Education, 3(2), 93-102. https://doi.org/10.31002/ijose.v3i2.1178

Lestari, I., \& Pratama, M. H. (2020). Pemanfaatan TIK Sebagai Media Pembelajaran dan Sumber Belajar oleh Guru TIK. Edumatic: Jurnal Pendidikan Informatika, 4(2), 95102.

Maisiswati, B. H., Ismatulloh, K., \& Uska, M. Z. (2018). Pengembangan Media Pembelajaran CD Tutorial Interaktif Pada Mata Pelajaran Simulasi Digital. Edumatic: Jurnal Pendidikan Informatika, 2(2), 66-73.

Marsa, A. R., \& Yunita, R. (2019). Website Media Pembelajaran Matematika Berbasis Moodle Platform (Studi Kasus: D3 Teknik Komputer STTP). JOISIE (Journal Of Information Systems And Informatics Engineering), 3(1), 1-9.

Maulana, I. (2020). Pengembangan E-Learning Berbasis Moodle. Jurnal Media Aplikom, 12(1), 1-12. https://doi.org/https://doi.org/10.33488/1.ma.2.1.247

Muazizah, N. M., Nurhayati, S., \& Cahyono, E. (2016). Keefektifan Penggunaan E-Learning Berbasis Moodleberpendekatan Guided Inquiry Terhadap Hasil Belajarsiswa. Jurnal Inovasi Pendidikan Kimia, 10(2), 1760-1768.

Munir. (2009). Pembelajaran Jarak Jauh Berbasis Teknologi Informasi dan Komunikasi. Bandung; Alfabeta.

Nikmah, M. (2015). Developing Moodle - Based Interactive Online Media To Teach Narrative Reading in Sma N 13 Semarang. Vision: Journal for Language and Foreign 
Language Learning, 4(1), 53-72. https://doi.org/10.21580/vjv4i11633

Quesada, J., Calvo, I., Sancho, J., Sainz, J. A., Sanchez, J., Gil-Garcia, J. M., Sebastian, R., \& Castro, M. (2013). Combining moodle and redmine as e-learning tools in Project Based Learning of Industrial Electronics. 2013 7th IEEE International Conference on $e$ Learning in Industrial Electronics, ICELIE, 86-91. Austria: IEEE. https://doi.org/10.1109/ICELIE.2013.6701278

Siddik, B., \& Kholisho, Y. N. (2019). Pengembangan Modul Pembelajaran Perakitan Komputer Berbasis Multimedia Interaktif. Edumatic: Jurnal Pendidikan Informatika, 3(1), 13-19.

Sopiatin, P. (2010). Manajemen Belajar Berbasis Kepuasan Siswa. Bogor: Ghalia Indonesia.

Sudianto, Dwijanto, \& Dewi, N. R. (2019). Students' Creative Thinking Abilities and Self Regulated Learning on Project-Based Learning with LMS Moodle. Unnes Journal of Mathematics Education Research, 8(1), 10-17.

Sugiyono. (2006). Metode Penelitian Pendidikan Pendekatan Kuantitatif, Kualitatif, dan $R \& D$. Bandung: Alfabeta.

Trianto. (2012). Mendesain Model Pembelajaran Inovatif-Progresif Konsep Landasan dan Implementasinya pada KTSP. Jakarta: Kencana. 